\title{
Influence of heat treatment on properties of solid bonded AISi11 alloys from chips
}

\author{
Wpływ obróbki cieplnej na własności stopu AISi11 \\ konsolidowanego plastycznie z wiórów
}

\section{PIOTR NOGA MARCEL WIEWIÓRA AGATA WZOREK*}

The paper presents study results on AISi11 alloy, which was obtained by extruding chips obtained from turning process. Mechanical properties from uniaxial tensile test and Vickers hardness test were determined. The influence of aging conditions on mechanical properties was invetsigated.

KEYWORDS: AISi11, precipitation hardening, solid bonding, export of aluminum scrap

Recycling of light metals is mainly carried out by melting. In the case of highly-finely divided scrap (for example, chip after machining), the material loss during the process is very high and only about $40 \%$ of the batch material can be recovered. Hence, it can be concluded that the export of aluminum scrap from Poland to European and Indian countries (fig. 1) is so high due to the low profitability of recycling. For example, in 2014 the value of aluminum scrap exported from Poland amounted to PLN 844 157. In order to avoid losses, it is possible to use plastic compression technology based on the extrusion method [1-4].

The popularity of silumin in the casting industry is a natural consequence of their exceptional properties such as good durability, crack resistance and low casting shrinkage. Thanks to these features, AISi alloys have been widely used in the automotive industry. pistons and combustion engine heads and gearbox housings [5] These properties are partly due to the presence of silicon in the inner structure, which positively influences the

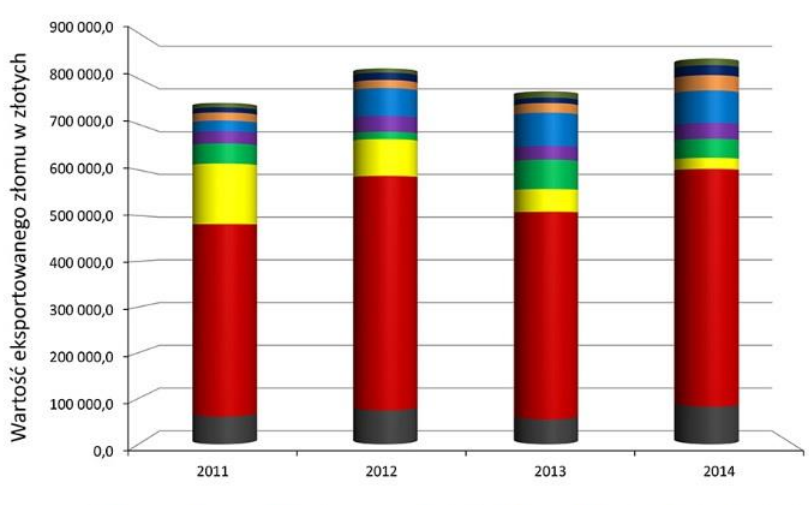

Fig. 1. Main directions and value of aluminum scrap exported from Poland in 2011-2014 [4]

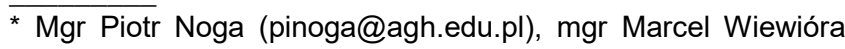
(marcelw@agh.edu.pl) - Wydział Metali Nieżelaznych AGH w Krakowie; mgr Agata Wzorek (aga.wzorek@gmail.com)-Wydział Zarządzania AGH w Krakowie
}

DOI: https://doi.org/10.17814/mechanik.2017.7.92

AISi alloys have been particularly popular recently. Alloys, such as $\mathrm{Cu}$ and $\mathrm{Mg}$, significantly increase the strength of the alloy while reducing its plasticity. In commercial applications, the amount of this element does not exceed $22 \%$ [6].strength of these alloys. Sizing at an around-eutectic temperature results in the dissolution of unequal, $\mathrm{Cu}$ and $\mathrm{Mg}$-rich particles while the composition of the alloy itself is homogenized. In addition, silicon is subjected to spheroidization during siliconization, which translates into final mechanical properties. The key parameter of the super-saturation process is proper temperature selection. Too low temperatures can cause only partial dissolution of nonequilibrium particles and consequently weakening of the later strengthening effect. A separate problem is iron containing particles (eg, Al8Mg3FeSi6, Al5Cu2Mg8Si6), which are particularly difficult to dissolve [7]. In case of AlSiMg alloys, the secretion sequence during the aging process can be presented as follows [8]:

$$
\begin{aligned}
\text { SSS } & \rightarrow \text { clusters (containing Mg and/or Si) } \\
& \rightarrow \text { zones GP } \rightarrow \beta^{\prime \prime} \rightarrow \beta^{\prime} \rightarrow \beta
\end{aligned}
$$

As a result of aging, the over-saturated solution contains clusters rich in $\mathrm{Si}$ and $\mathrm{Mg}$, which are subsequently transformed into zones GP and metastable, coniferous $\beta^{\prime \prime}$. These particles are responsible for a significant increase in the strength of the secretory strengthening process. Further annealing can lead to melt stop and produce metastable $\beta$ ' phases. In quaternary alloys such as AISiCuMg, there may be additions of $Q$ and $\Theta^{\prime}[9]$.

\section{Methodology of research}

The starting material for the study was AISi11 alloy chips (fig. 2a), which were obtained in a rolling process without the use of a cooling agent on a TUM 35 lathe (alloy composition is shown in Table I). The cutting process was carried out at a spindle speed of $315 \mathrm{rpm}$, with a knife feed of $0.2 \mathrm{~mm} / \mathrm{s}$ in the direction of the material axis. The resulting chips are labeled AISi11 TM. The next preparatory stage was pre-compaction of the chips in the hydraulic press with a maximum pressure of $100 \mathrm{tf}$. The 25 grams of weight was placed in a cylindrical press chamber, and then the piston was pushed with a pressure of $30 \mathrm{tf}$ by means of a punch. In this way, eight moldings with a diameter of $\varnothing 38 \mathrm{~mm}$ and a height of 10 $\mathrm{mm}$ were obtained, which constituted the charge for the extrusion process (fig. $2 \mathrm{~b}$ ). 
a)

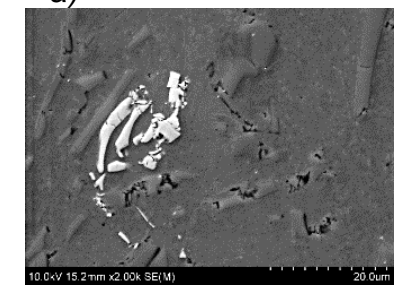

b)

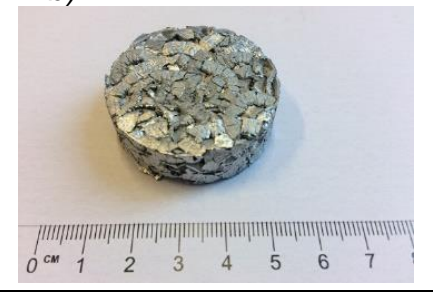

Fig. 2. Microstructure of AlSi11 alloy chip (a), compacted from AlSi11 alloy chips (b)

TABLE I. Composition of the test alloy, \% mass

\begin{tabular}{|c|c|c|c|c|c|c|c|c|c|c|}
\hline $\mathrm{Si}$ & $\mathrm{Mg}$ & $\mathrm{Fe}$ & $\mathrm{Cu}$ & $\mathrm{Mn}$ & $\mathrm{Cr}$ & $\mathrm{Ni}$ & $\mathrm{Zn}$ & $\mathrm{Ti}$ & $\mathrm{Zr}$ & $\mathrm{Al}$ \\
\hline 10,58 & 0,28 & 0,38 & 0,51 & 0,24 & 0,03 & 0,12 & 0,10 & 0,011 & 0,06 & rest \\
\hline
\end{tabular}

The co-extrusion using concurrent technique was carried out at $450{ }^{\circ} \mathrm{C}$ with an extrusion speed of $1 \mathrm{~mm} / \mathrm{s}$. In comparison, a solid aluminum alloy ingot was affixed under the same conditions as AISi11 IM. The squeezed bars were $\varnothing 8 \mathrm{~mm}$ in diameter.

The rods were subjected to Vickers hardness tests according to PN-EN ISO 6507-1 using 19.61 N (HV2) load. The test specimens, prepared from the extruded bar, were placed in an oven heated to $525^{\circ} \mathrm{C}$. They were kept at this temperature for $30 \mathrm{~min}$ and then transferred to water. Artificial aging was then carried out at $160{ }^{\circ} \mathrm{C}$ and $180{ }^{\circ} \mathrm{C}$ with different aging times. After heat treatment, Vickers hardness measurement was performed. For a material aged at $160{ }^{\circ} \mathrm{C}$ for 4 hours, a single-axis tensile test at ambient temperature according to EN ISO 6892-1 was performed.

\section{Test results}

TABLE II. Mechanical and physical properties of tested materials after extrusion

\begin{tabular}{|l|c|c|}
\hline & AlSi11 IM & AlSi11 TM \\
\hline $\begin{array}{l}\text { Tensile strength } R m, \\
\mathrm{MPa}\end{array}$ & 189 & 200 \\
\hline $\begin{array}{l}\text { Yield strength } R_{0,2}, \\
\mathrm{MPa}\end{array}$ & 85 & 87 \\
\hline Elongation $A, \%$ & 14,5 & 17,5 \\
\hline Hardness, $\mathrm{HV}$ & 72 & 67 \\
\hline Density, $\mathrm{g} / \mathrm{cm}^{3}$ & 2,66 & 2,65 \\
\hline
\end{tabular}

a)

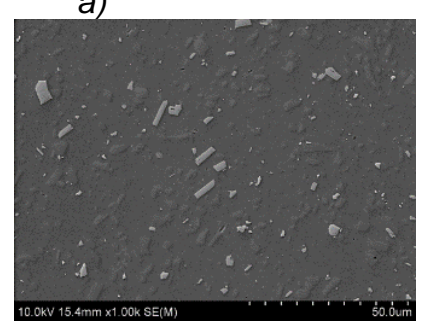

Fig. 3. Microstructure of AISi11 chip alloy bar (a), AlSi11 solid alloy bar structure (b)

TABLE III. Mechanical properties of tested materials after heat treatment, determined on the basis of fig. 6

\begin{tabular}{|l|c|c|c|}
\hline & $\begin{array}{c}\text { Tensile stre- } \\
\text { ngth } R m, \\
\mathrm{MPa}\end{array}$ & $\begin{array}{c}\text { Yield strength } \\
R_{0,2}, \mathrm{MPa}\end{array}$ & $\begin{array}{c}\text { Elongation } \\
A, \%\end{array}$ \\
\hline AlSi11 IM T6 & 336 & 190 & 11,9 \\
\hline AlSi11 TM T6 & 329 & 188 & 10,9 \\
\hline
\end{tabular}

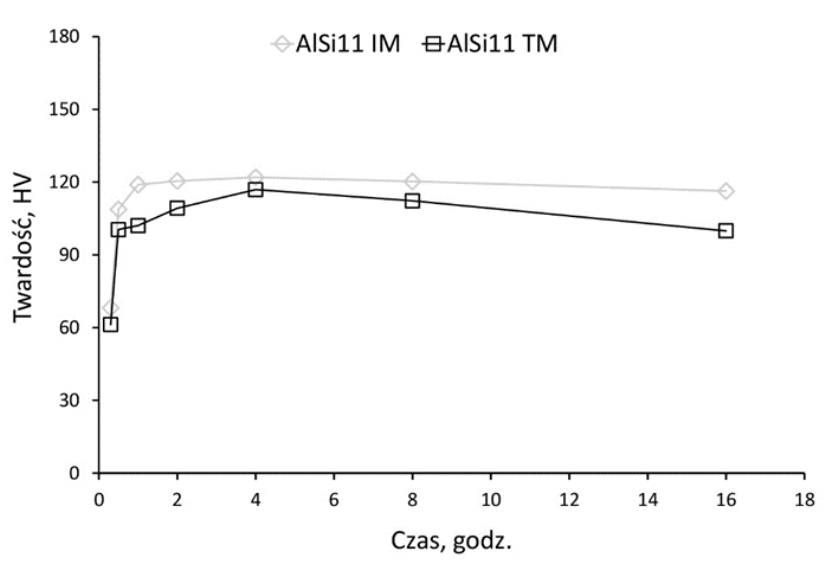

Fig. 4. Changes in hardening of AISi11 (TM and IM) alloys hardened at $160{ }^{\circ} \mathrm{C}$

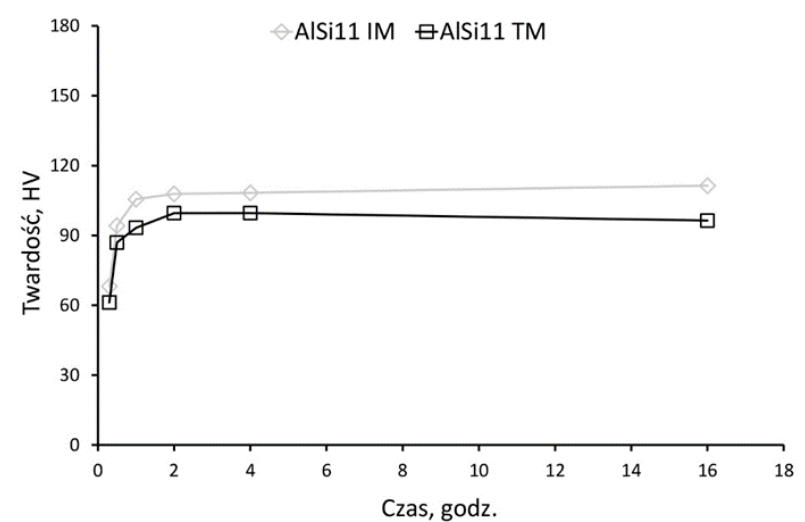

Fig. 5. Changes in hardening of AISi11 (TM and IM) alloys hardened at $180^{\circ} \mathrm{C}$

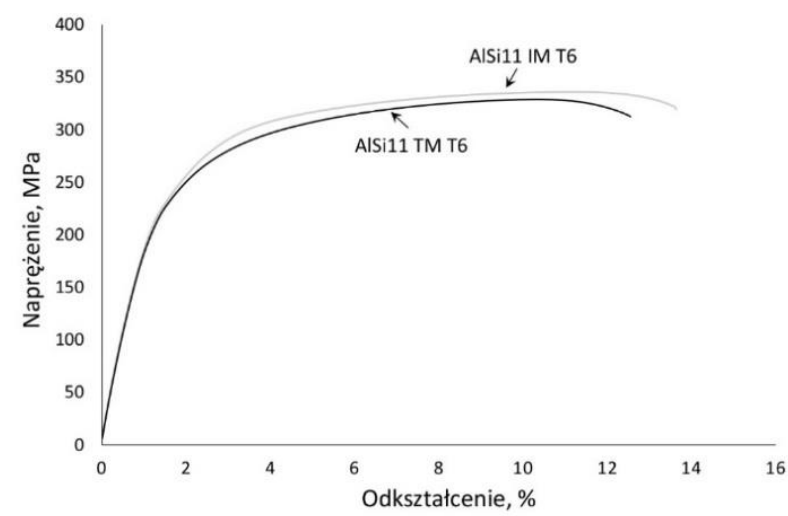

Fig. 6. AISi11 (IM and TM) alloy stretching curves after heat treatment to T6 condition - combined with aging (aging at 160 ${ }^{\circ} \mathrm{C}$ for $4 \mathrm{~h}$ )

\section{Analysis of results}

Low efficiency of fine scrap processing results in large material losses. The recycling concept based on the plastic consolidation process offers the opportunity to reduce these losses and significantly reduce the energy consumption of the process. Consolidation of AISi11 alloys by extrusion at elevated temperatures results in bars with a smooth, glossy surface, comparable to extruded solid material. The selection of appropriate parameters of the plastic consolidation process $\left(450{ }^{\circ} \mathrm{C}\right.$ and extrusion speed of $1 \mathrm{~mm} / \mathrm{s}$ ) allowed to produce material which is characterized by lack of surface defects (cracks, delamination).

In the structure of the bar extruded from chips, the presence of brittle, primary crystalline silicon crystals with sharp edges and fragile AlFeSi intermetallic phases were 
observed. The chip extruded from the chips is characterized by a significant fragmentation of the Si and AIFeSi phases as compared to the phases visible on the microstructure of the rod extruded from the solid ingot (fig. 3). This shows that the silicon has been crushed during the cutting process. Release of silicon has a significant impact on the improvement of AISi strength properties.

The mechanical properties of the squeezed bars were tested in a tensile test and a hardness test. Extruded bars exhibit similar strength properties with slightly higher elongation values for AISi11 TM alloy (Table II). The hardness of AISi11 IM was $72 \mathrm{HV}$, while AISi11 TM - 67 HV (Table II).

The material extruded from the chips has a comparable density with the material extruded from the solid ingot. Alloys ( $\mathrm{Si}, \mathrm{Mg}$ ) improve the strength properties and favorably affect the material's ability to heat. The optimum time-temperature conditions for the curing process were determined by artificially aged materials at $160{ }^{\circ} \mathrm{C}$ and $180^{\circ} \mathrm{C}$ (fig. 4, fig. 5). After aging at $180^{\circ} \mathrm{C}$ for $4 \mathrm{~h}$, the hardness of the materials was 108 HV for AISi11 IM and $100 \mathrm{HV}$ for AISi11 TM and did not change even after artificial aging for $16 \mathrm{~h}$ (no visible effect). From the point of view of maximizing the strength properties of the material obtained from chips, it is possible to consider artificial aging at $160{ }^{\circ} \mathrm{C}$ for $4 \mathrm{~h}$, which results in a hardness of $117 \mathrm{HV}$ as the most favorable (fig. 4). This hardness is the maximum on the aging curve, and when this value is exceeded, there is a decrease in the strength properties associated with the effect of the aging.

The hardness results for the rod obtained from the chips are similar to those for the bar extruded from the solid material. Aging at $160{ }^{\circ} \mathrm{C}$ for $4 \mathrm{~h}$ gives a tensile strength of $329 \mathrm{MPa}$ for AISi11 TM and a yield strength of $188 \mathrm{MPa}$. It should be stressed that these results are slightly worse than those for AISi11 IM alloy (fig. 6, Table III). The curing process has resulted in a significant increase in the strength properties of both solid and chip extruded materials. The used AISi11 recycling method allowed the material to obtain mechanical properties comparable to that of the solid material of the solid ingot.

\section{Conclusions}

- Because of the high loss of recycled aluminum scrap, its exports from Poland are quite high.

- Pre-pressing of chips and selection of suitable extrusion parameters allowed to obtain material characterized by good consistency and lack of porosity.

- Molded materials - both solid and chip - are characterized by hardness of $60 \mathrm{HV}$. The bars have a high tensile strength (about $200 \mathrm{MPa}$ ) and an elongation of $15 \%$.

- Artificial aging AISi11 aluminum alloy foundry has a significant impact on the strength properties. Heat treatment for T6 (super-saturation and aging) results in a high strength of the materials at a slight decrease in plasticity relative to the starting material.

- Through the plasticity of the alloys AISi11, a rod has been obtained with properties comparable to the properties of the extruded bar of the solid ingot.

\section{REFERENCES}

1. Green J. "Aluminum recycling and processing for energy conservation and sustainability". ASM International. Clevlend, 2007. ISBN: 978-0-87170-859-5.
2. Dybiec H. "Plastic consolidation of metallic powders". Archive of Metall.\&Mater. 52 (2007): pp. 161-170.

3. Chmura W., Gronostajski J. "Mechanical and tribological properties of aluminum - based composites produced by the recycling of chips". J.Mat.Procc.Technology. 106 (2000): pp. 23-27.

4. Opracowanie własne na podstawie danych z GUS.

5. Jarco A. "Poprawa plastyczności stopu AISi11 przez zastosowanie wyżarzania zmiękczającego" ("Improvement of plasticity of the AlSi11 alloy due to soft annealing treatment"). Prace Instytutu Odlewnictwa. LVI, 3 (2016): pp. 261-266, DOI: 10.7356/iod.2016.18.

6. Zolotorevsky V.S., Belov N.A., Glazoff M.V. "Casting aluminum alloys". Elsevier Science. 2007, ISBN 9780080453705.

7. Moustafa M.A., Samuel F.H., Doty H.W. "Effect of solution heat treatment and additives on the microstructure of $\mathrm{Al}-\mathrm{Si}$ (A413.1) automotive alloys". Journal of Materials Science. 38 (2003) pp. 4507-4522.

8. Colley L.J., Wells M.A., Poole W.J. "Microstructure-strength models for heat treatment of Al.-Si-Mg casting alloys I: microstructure evolution and precipitation kinetics". The Canadian Journal of Metallurgy and Materials Science. 53, pp. 125-137, 2014 Issue 2.

9. Tavitas-Medrano M.A., Samuel F.H., Doty H.W. "Effect of solution heat treatment and additives on the microstructure of Al-Si (A413.1) automotive alloys". Journal of Materials Science. 38 (2003) pp.4507-4522. 